\title{
MATSUI Keisuke: Geography of Religion in Japan: Religious Space, Landscape, and Behavior
}

Tokyo: Springer Japan, xii+199 pp., 2014 (ISBN 978-4-431-54549-1).

This is the first English-language book detailing the research trends in and main topics of Japanese religious geography over the last quarter century. A short introduction on this book has already appeared in Englishspeaking countries (MacWilliams 2016). The book primarily consists of English translations and minor re-editions of parts of the author's previous books in Japanese, one of which is his most important work (Matsui 2003) and the other, in my opinion, is virtually for general readers rather than scholars (Matsui 2013). These two books are both favorably and critically reviewed in Japanese geographical journals (Sato 2014; Yoshida 2014; Oda 2004, 2015).

This English book consists of four chapters and a conclusion. The first chapter reviews research trends in Japanese religious geography including extensive historical geography works. The author classifies the "current topics" into four subfields: 1) spatial structures of distribution and diffusion of religions; 2) cultural landscapes and social groups influenced by religions; 3 ) the relationships between religion and fudo (milieu) or the natural environment; and 4) pilgrimage, tourism, and sacred places. However, it is somewhat unclear whether or not these four themes entirely correspond to another series of four topics that he separately enumerates as "recent trends" on pages 10 and 196.

The second chapter briefly introduces the Japanese people's worship of sacred landscapes, such as trees, rocks, and torii (archways to Shinto shrines). It also proposes an abstracted spatial model of Japanese rural communities advocated by the religious scholar Hitoshi Miyake (not Jun Miyake), which is well-known, especially in Japanese folklore studies. This chapter on the relationships between religions and the natural environment reconfirms existing general findings, at least for Japanese readers, by applying the author's original fieldwork.

The third chapter is the highlight of the book and includes two massive case studies, presenting a large number of fine figures and tables. It first focuses on the belief or distribution area of worshippers (the "catchment area" as denoted in this book) of the Kasama Inari Shrine in Ibaraki Prefecture, which is internally classified into three concentric zones (within 50 kilometers, 50-150 kilometers, and $150-800$ kilometers from the shrine). This is highly detailed research, based on the shrine office's nominal lists of believers. The chapter also examines another belief area of the Kanamura Wake Ikazuchi Shrine, also in Ibaraki prefecture, and its believers' activities in rural communities near the shrine, including in neighboring Saitama Prefecture. The author conducted very intensive fieldwork, effectively using unpublished registers in the shrine office, interviews with local residents of the communities, and landscape observations.

This chapter is valuable in that it uncovers not only a concentric "doughnut" structure, which is different from the standard concentric circles structures of the Japanese belief areas of mountaintop Shinto shrines, but also sectoral zones within the Kasama Shrine belief area. However, the discussion section of the chapter is too short and does not fully explore the effects of the Tokyo metropolitan area as a megacity within this structure. In addition, the section on the Kanamura Shrine case study includes some careless errors that are not found in the original Japanese book (Matsui 2003: 180-194): the first paragraph of page 123, which is assigned as the description for Fig. 3.50 (a schematic model of the Kanamura faith for local communities), actually corresponds to Fig. 3.49 (showing religious behavior by residents of a local community); Fig. 3.50 is not explained in this paragraph; the last paragraph of page 128 applies to Fig. 3.50 and not Fig. 3.51 (a schematic model of the Kanamura belief area); and Fig. 3.51, one of the most important concluding figures in the chapter, is not explained at all.

The fourth chapter explores the current topic of the revitalization of urban and rural communities through the promotion of religious tourism, based on the author's fieldwork. It first focuses on landscape changes in a shopping street (monzenmachi) for tourists, including foreign visitors, stretched between two railway stations to the Naritasan Shinshoji Temple in Chiba Prefecture. The chapter next discusses the commodification of Catholic churches in Nagasaki Prefecture, including small remote islands through a World Heritage registration movement, by exemplifying newly invented pilgrimage routes for 
tourists. However, this chapter lacks integrated analyses and discussions based on the two case studies of the Naritasan Temple and Nagasaki churches. Moreover, its perspective is too general to critique recent discussions in the social sciences on the commodification of sacred sites and rurality.

This book carefully covers all four themes of Japanese religious geography specified in the first chapter. However, the conclusion fails to provide any substantial conclusions. It solely duplicates the summaries of the four chapters and neglects to set forth new findings or close discussions based on the logical integration of each chapter's results. The conclusion therefore does not present any theoretical and abstracted findings based on the author's valuable case studies or comparison with previous publications on these four topics of religious geography in Japan and the world (or at least English-speaking countries).

In other words, this book presents only minute reports of fieldwork fact findings. In addition, it does not clearly provide any answers to the three future directions of Japanese religious geography that are delineated in the first chapter: 1) elucidating the nature of religion itself from the perspectives of religious geography; 2) exploring the religious realities of contemporary Japan; and 3) examining Japanese syncretism, in which various religions coexist without inconsistency. Readers will, however, discover a research frontier, including strong points and shortcomings, of the present Japanese religious geography in this laborious book.

\section{References}

MacWilliams, M. 2016. Review of Geography of religion in Japan: Religious space, landscape, and behavior by Keisuke Matsui. Religious Studies Review 42: 57.

Matsui, K. 2003. Nihon no shukyo kukan (Religious spaces in Japan). Tokyo: Kokon Shoin. (J)

Matsui, K. 2013. Kanko senryaku toshiteno shukyo: Nagasaki no kyokaigun to basho no shohinka (Sacred sites for tourism strategy: The Nagasaki churches and the commodification of place). Tsukuba: Tsukuba Daigaku Shuppankai. (J)

Oda, M. 2004. Shinkoken kenkyu no chirigakuteki kadai: Matsui Keisuke cho "Nihon no shukyo kukan" o hyoshite (Geographical themes in the study of worship catchment area: A review of Religious space of Japan by Keisuke Matsui). Komazawa Chiri (Komazawa Geography) 40: 105-120. (J)

Oda, M. 2015. Review of Kanko senryaku toshiteno shukyo: Nagasaki no kyokaigun to basho no shohinka (Sacred sites for tourism strategy: The Nagasaki churches and the commodification of place) by Keisuke Matsui. Komazawa Chiri (Komazawa Geography) 51: 59-63. (J)

Sato, D. 2014. Review of Kanko senryaku toshiteno shukyo: Nagasaki no kyokaigun to basho no shohinka (Sacred sites for tourism strategy: The Nagasaki churches and the commodification of place) by Keisuke Matsui. Geographical Review of Japan 87A: 329-331. (J)

Yoshida, K. 2014. Review of Kanko senryaku toshiteno shukyo: Nagasaki no kyokaigun to basho no shohinka (Sacred sites for tourism strategy: The Nagasaki churches and the commodification of place) by Keisuke Matsui. Geographical Sciences (Chiri Kagaku) 69: 37-39. (J)

(J) written in Japanese

IMAZATO Satoshi Faculty of Humanities, Kyushu University 